\title{
RELIGION AND BANKING SYSTEM: THE FUTURE OF SYARIAH BANKING PRACTICES Historical and Contemporary Fiqh Perspectives
}

\author{
Hamka Siregar \\ IAIN Pontianak
}

\begin{abstract}
The momentum of the development of Sharia banking has been noticed since the 1970s, which generally had two patterns: first, establishing the Islamic bank side by side with conventional one (dual-banking system) as practiced in Egypt, Malaysia, Saudi Arabia, Jordan, Kuwait, Bahrain, and Bangladesh; and second, restructuring the banking system as a whole in accordance with Islamic Sharia (full-fledged Islamic financial system) as applied in Sudan, Iran and Pakistan. The development of the Sharia-based banks which have been established across the world since the 1970s, became the motivation of the Indonesian ulemas to draft law on Sharia banking, so that Sharia banking could also be developed. As a result, these last few years, the banking world in Indonesia has witnessed the establishment of the public Sharia banks and Sharia business units, like Bank Muamalat and Bank Syariah Mandiri to mention a few. Using historical and contemporary jurisprudence perspective, this paper provides discussion on the future of Sharia banking.
\end{abstract}

Keywords: Sharia banking, Future

\section{INTRODUCTION}

Sharia banking is a banking system which was developed based on the Islamic Sharia (law). In this context, according to the history of the Muslim economic system, the funding which is carried out by the appropriate approval of Sharia has become part of the tradition of Muslims since the days of the Prophet. Practices like accepting entrusted estate, lending money for consumption and business purposes, as well as doing money transfer, has commonly been done since the age of the Prophet. This indicated that the three main functions of the bank i.e. accepting deposits of money, lending money, and providing money transfer services have been in practice. Therefore, the main functions of modern banking, such as accepting deposits, channeling funds, and doing transfer of fund have in fact been known even become inseparable from the economic wheels of the Muslims since the days of the Prophet.

Since 1970s the momentum of the Sharia banking development has 
been felt. In general it had two patterns i.e., first, establishing the Islamic bank side by side with the conventional one (dual-banking system) as practiced in Egypt, Malaysia, Saudi Arabia, Jordan, Kuwait, Bahrain, and Bangladesh; and second, restructuring the banking system as a whole in accordance with Islamic Sharia (full-fledged Islamic financial system) as implemented in Sudan, Iran and Pakistan (Wibisono, 2009: 3).

In Iran, Islamic banks have been operating after the interest-free Banking Law was passed in August 1983 and took effect in March 1983. This led to the rapid developments of Islamic banks in Iran to this day. It is also the case with Sudan, which in 1978 started to operate under the name "Faisal Islamic Bank of Sudan" With a Special Decree, the entire banks of Sudan were Islamized. Then, Bank Islam Malaysia began operation in July 1983 after the legalization of the Sharia banking Law No. 276 in March 1983. Based on the Temporary Law No. 13 which was further reinforced by Permanent Law number 62/1985 then the Sharia-based bank began operation in Jordan under the name "Jordan Islamic Bank for Finance and Investment" (Wibisono, 2009: $4)$.

The development of Sharia-based banks that have been established across the world since the 1970s, became the motivation for Indonesian ulemas to draft the Sharia banking law, so that Sharia banking could be developed. As a result, these last few years, the banking world in Indonesia has witnessed the establishment of the public Sharia banks and Sharia business units, like Bank Muamalat and Bank Syariah Mandiri to mention a few. This is an indication that more and more Indonesian people prefer the Islamic ways of transactions. This condition also showed that the public is starting to be aware of the existence of Sharia banking as a means for them to manage the deposited funds based on the principles of Islamic Sharia. Another factor is that the conventional banking system is considered incompatible with the culture of Indonesia where the majority of the citizens are Muslims.

Using historical and contemporary jurisprudence perspective, this paper will discuss the future of Sharia banking.

\section{SHARIA BANKING: FROM THE TIME OF THE PROPHET TO THE CONTEMPORARY}

According to the Law of the Republic of Indonesia No 21/ 2008 on Sharia banking Chapter I: General Provisions, Article 1 makes it clear that Sharia banking is anything that concerns Islamic banks and Sharia Business Units, including institution, business activities, as well as the manner and process in carrying out its business activities. While the Sharia bank is a bank that 
runs its business activities based on Sharia principles and based on is type including Sharia public banks and Shariah public financing banks. A Sharia public bank is a Sharia bank whose activities are among others providing services in payment transactions. While a Sharia public financing is a bank that does not provide services in payment transactions.

Sharia business units (abbreviated as UUS) is a unit of work of the headquarters of a conventional commercial bank that serves as the main office of the office or unit that carries out business activities based on Sharia principles, or a unit of work in the branch office of a bank located overseas that carries out conventional business activities in an office which serves as the main office of the supporting branch office of a Sharia bank and/or Sharia unit. A branch office is an office of a branch of the Islamic bank liable to the headquarters of the bank with a concrete place of business address corresponding to the location of the branch office.

While according to Karnaen A. Perwataatmadja and H.M Syafi'i Antonio (1997: 14), the Islamic bank or Sharia bank is a bank that operates in accordance with the principles of the Sharia and its ways of operation refer to the provisions of the Qur'an and the Hadith.

The emergence of Sharia banking which is taking part of the historical development of banking in the contemporary era, has in fact been part of the tradition of Muslims since the era of Prophet Muhammad and has grown until the contemporary era today. With regard to the genealogy of Sharia banking from the era of Prophet Muhammad to the contemporary, the author describes as follows (Adiwarman A. Karim, 2004: 14-26):

\section{The Era of the Prophet}

History noted how the Messenger of Allah, known as al-Amin, was trusted by the people of Mecca to care for their estate, so at the last moment before the Hijra to Medina, he asked Ali to return the estate to all who possessed it. In this concept, the person --whom people entrust their estate to-cannot take advantage of the estate. A companion of the Prophet, Zubair Ibn Awwam, chose not to accept entrusted estate. He would prefer to accept it in the form of loans. Zubair's action had different implications. First, by taking the money as a loan, he had the right to use it. Second, because its loan, he obligated to return it in full.

Other companion, Ibn Abbas was reported to perform money transfer to Kufah. Also Abdullah ibn Zubair in Mecca had some money delivered to his younger brother, Misab ibn Zubair, who lived in Iraq. The use of checks was 
also recognized in line with the growing trade between Palestine and Yemen, which lasted at least twice a year. Even during the reign of Umar Ibn Khattab, he was using checks to pay benefits to those who were entitled. With this check then they could exchange it with wheat at Baitul Maal which was imported from Egypt. In addition, the provision of capital for profit-sharing based businesses, such as the mudharabah, musyarakah, muzara'ah, musaqah, have been known since long ago between the Muhajirun and the Ansar.

It is clear that there were individuals who carried out banking functions at the time of the Prophet. Some companions carried out the function of caring for someone else's estate; some provided loans, money transfer service, and capital to start a business.

A few terms of modern banking even originated from the corpus of the Fiqh. The term credit, for example,(English: credit; Latin:credo) which was taken from the term qard. Credit in English means lending money; credo means trust; meanwhile the term qard in Fiqh means lending money on the basis of trust. The term check French: cheque) is derived from the word saq (suquq). Suquq in Arabic means market, whereas a check is a tool commonly used to make payment in the market.

\section{The Period of the Umayyah and Bani Abasiah}

Obviously the banking institution was unknown in the Islamic jurisprudencevocabulary, because it was unknown to the Muslims in the time of the Prophet, the Khulafur Rasyidin, the Umayyah Caliphs, and the Abbasids. However banking functions, such as accepting deposits, disbursing funds, and transferring money were common practice done in accordance with Sharia. At the time of the Prophet, the banking functions were performed by individuals, and usually only one person doing one function only. It was only later, in the age of the Abbasids, the three banking functions were carried out by an individual in the history of Islam. Banking began to develop rapidly when many types of currency were circulating in those days so that it required special skills to distinguish between the currencies. It was necessary because each currency had different gold content. People with this special expertise was called naqid, sarraf, and jihbiz. This was the forerunner of the money changing practice.

The term has been known as jihbiz since the time of Muawiyah (661-680 AD) which is actually derived from Persian, kahbad or kihbud. During the reign of Sasanid, the term was used for a person who was assigned to collect the land tax. The role of the bankers at the time of the Abbasid Caliphs began to become popular during the Muqtadir Administration (908-932M). At the time, 
almost every vizier had its own bankers. For example Ibn Furat appointed Harun Ibn Imran and Yusuf Ibn Wahab as his bankers. Then Ibn Ali Isa appointed Ali ibn Isa, Hamid Ibn Wahab appointed Ibrahim ibn Yuhana, even Abdullah Al-Baridi had three bankers at the same time: two Jews and one Christian.

The advancement of the banking practices of that era was marked with the release of saq (check) as a medium of payment. The role of the banker had even covered three aspects, i.e. accepting deposits, channeling, and transfering money. In the latter case, money could be transferred from one country to another without the need to physically transport it. Money changers who set up offices in many countries have begun to use checks as a medium of money transfers and other payment activities. In the history of Sharia banking, Syaf Al-Dawlah Al-Hamdani is reported as the first person to issue a check for clearance between Baghdad (Iraq) and Aleppo (current day Spain).

\section{The Development in Europe}

In a further development, the activities carried out by individuals with regard to jihbiz later were undertaken by an institution which is currently known as a bank. When the European banks began banking practices, problems began to arise because transactions carried out were interest-based. In the view of Islamic jurisprudence, the interest is known as riba (usury), and therefore forbidden. This interest-based transactions increasingly were very common when King Henry VIII in 1545 allowed interest though still banned riba on condition that the interest should not be excessive. When King Henry VIII died, he was succeeded by King Edward VI who forbade the application of interest. This however did not last long. When he died, he was succeeded by Queen Elizabeth I who revived the interest system.

Then, Europeans began to awaken from from backwardness and went through the period of renaissance. Exploration and colonization started to occur all over the world, and the activities of the world's economy began to be dominated by Europeans. At the same time, Muslim civilization suffered deterioration and Muslim countries fell into the grip of colonial Europeans one after another. As a result, the Muslim economic institutions collapsed and were replaced by the European's. This state of affairs has continued until modern times. Because current existing banking institutions in majority Muslim countries are a legacy of the Europeans, most transactions are interest-based.

\section{Modern times and Contemporary Era}

Furthermore, there have efforts in a number of Muslim countries to establish 
alternative institutions against the conventional interest-based banks, since the interest system in Fiqh is categorized usury (and therefore forbidden). This happens especially after Muslim nations gain independence from European colonization. The first modern attempt to set up the bank without interest was first conducted in Malaysia in the mid 1940s. However, the efforts were to no avail.

Another attempt was made in Pakistan at the end of the 1950s, where an financial institution ran without interest was established in a rural area of the country. Nevertheless, the experiment of the establishment of Islamic banks that was the most successful and innovative in the modern times one founded in Egypt in 1963, with the establishment of of Mit Ghamr Local Saving Bank. The Bank got a pretty warm reception in Egypt, mainly from among farmers and rural communities. The number of customers of the bank increased from the first year $17,560(1963 / 1964)$ to 251,152 in $1966 / 1967$. The amount of savings increased drastically from LE $40, .944$ at the end of the first year (1963/1964) to LE 1,828,375 at the end of the period of 1966/1967. Unfortunately, due to political turmoil in Egypt, Mit Ghamr began to decline, so that its operation was taken over by the National Bank of Egypt and the Central Bank of Egypt in 1967. The takeover led to the principle of interest-free system of the Mit Ghamr started to be left behind, so the bank was back in operation based on interest. In 1971 eventually the concept of interest-free was revived during the Sadat regime through the establishment of Nasser Social Bank. The purpose of this bank was to run a business based on the concept of that was been practiced by the Mit Ghamr.

The success of Mit Ghamr became a source of inspiration for Muslims across the world, especially the fact that they realized that the principles of Islam apparently can still be applied in modern business. When the OIC (Organisation of Islamic Cooperation) was finally formed, a series of international conferences began to take place, where one of its economic agenda was the establishment of Islamic banks. Eventually, the Islamic Development Bank (IDB) was founded in October 1975 by 22 Islamic countries. The Bank provided financial support for the development of its member countries, helping them to set up an Islamic bank in their respective country, and played an important role in the study of Islamic Economics, banking and finance. Now, the bank is based in Jeddah-Saudi Arabia and has had more than 43 member States.

Later in the 1970s, attempts to establish Islamic banks were beginning to spread to many countries. Some countries, such as Pakistan, Iran, and Sudan, even changed the entire financial system of the country in order to adopt an interest-free system, so that all financial institutions in the 
country could operate without the use of interest. In other Muslim countries such as Malaysia and Indonesia, Islamic banks operated side by side with conventional ones. Now, Sharia banking has undergone a pretty rapid advance and spread to many countries, even to the West. The Islamic Bank International of Denmark is recorded as the first Islamic bank operating in Europe, founded in 1983 in Denmark. Now, the major banks of Western countries such as Citibank, ANZ Bank, Chase Manhattan Bank, and Jardine Fleming have also opened the Islamic window in order to provide banking services that comply with Islamic jurisprudence.

In terms of the process of evolution, embryonic banking activities in Islamic society were conducted by individuals to single banking functions. Then, the profession of jihbiz developed, that is an individual doing the three banking functions. Such activities were adopted by the European Community of the middle ages, and the operations were carried out by institutions, but the activities were interest-based. Due to the decline of the civilization of the Muslims and the colonization of Western nations against Muslim countries, the evolution of the practice of Sharia compliant banking was stuck a few centuries. In the 20th century, Muslim independent modern Islamic banks were founded in a number of countries and continued to go through further development.

\section{The Development in Indonesia}

In Indonesia, the first Islamic bank founded in 1992 is the Bank Muamalat. Though it was a bit late compared to other Muslim States, Sharia banking in Indonesia will continue to grow. Between 1992-1998 there was only one Islamic bank in Indonesia, then in 1999 the number increased to three. In the year 2000, the number of Islamic and conventional banks that opened Sharia business units increased to 6 . Meanwhile the number of BPRS (Sharia People's Loans Bank) have already reached 86 units and will still be growing. In the coming years, the number of Islamic banks will continue to increase with the influx of new players recently, increasing the number of branch offices of the existing Islamic banks, as well as the opening of the Islamic window in conventional banks.

The research carried out by Karim Business Consulting (2002) projected that the total assets of Islamic banks in Indonesia will grow by 1,850\% for 8 years, or an average of $356.25 \%$ each year. This is a very impressive growth. Growing Sharia banking assets is due to the certainty of regulation as well as the change of views among the community members regarding the presence of the Islamic banks. 
The development of Sharia banking certainly must also be backed up by sufficient human resources, both in terms of quality and quantity. However, the reality shows that there are still many people involved in the Sharia institutions have no practical or academic experience in Sharia banking. Surely this condition quite significantly affects the productivity and professionalism of Sharia banking itself. And this should in fact require the attention of all of us, particularly the resources that are able to practice Sharia economic system in all fields because a good system is unlikely to be able to run without good quality human resources.

\section{FOUNDATIONS OF SHARIA BANKING}

And whatever you give for interest to increase within the wealth of people will not increase with Allah. But what you give in zakah, desiring the countenance of Allah - those are the multipliers. (QS. Ar-Rum: 39)

Those who consume interest cannot stand [on the Day of Resurrection] except as one stands who is being beaten by Satan into insanity. That is because they say, "Trade is [just] like interest." But Allah has permitted trade and has forbidden interest. (QS.Al-Baqarah: 275)

The verses above quoted by authors to bring a kind of hypothesis in this article that the discourse and discussion about the virtues of Sharia banking in this contemporary era are still driven by the discourse of prohibition of riba (usury), which specifically leads to the prohibition of the conventional bank interest.

There are at least two fundamental opinions that address the issue of usury. The first opinion came from the majority of scholars who adopt and interpret the fuqaha regarding the riba as stated in fiqh. Another opinion says that the prohibition of usury is understood as something related to an attempt of exploitation, which has very detrimental impacts economically to the community.

Conventional bank interest controversy is still becoming a widely discussed issue in the community. Due to the interest provided by by conventional banks which is forbidden, and the Indonesia Ulema Council (MUI) already issued a fatwa in 2003. The discourse, however, still is still a subject of discussion a many arguments put forward to justify the interest that it is not synonymous with usury. Although the Qur'an and the Hadith are very clear with regard to usury which forbidden.

To address the controversy of bank interest and usury appropriately requires a deep understanding of the ins and outs of interest as well as of 
the consequences brought about by the application of the interest system in the economy and by reading the signs and the direction of the definition of usury in the Quran and Hadith.

The term interest according to the American Heritage Dictionary of the English Language, namely "a charge for a financial loan, usually a percentage of the amount loaned ". Interest is the amount of money paid for the use of capital. The amount stated for example with one level or percentage of the capital relevant with it which is called the interest of capital (Muhammad Mujahidin, 2010).

The original meaning of "riba" in Arabic is 'more' ('increased'). As for what is meant here by syara' here usury is the contract that goes with a particular exchange, but the amount is unknown or not according to the rules of sharia or belatedly accepted. (Sulaiman Rasjid, 2002: 290). The first known use of the term riba is based on the revelation handed down at the beginning of the prophetic period in Mecca most likely in the fourth year or the beginning of Hijra, especially in early period when verses related to usury were revealed. The classical exegetes argued that the meaning of riba here is 'a gift'. Based on this interpretation, according to Azhari (d. 370 H/980 AD) and Ibn Mandzur (d.711H/1331AD) consists of two forms of usury, one that is forbidden and the other is not. However, in reality the term riba is only used to interpret the value of the debt that added to the loan (Abdullah Saeed, 2003: 27). Meanwhile, al-Jurjani defined usury as an excess payment without any additional/replacement/return, required for one of the two parties that make contract/transaction (Muhammad Mujahidin, 2010).

In this light, generally there is a common definition which asserts that usury is an additional charge, both in buying and selling as well as loan that is wrong or contrary to the principles of muamalat in Islam. Regarding this, Almighty God reminds in His words: "O you who have believed, do not consume one another's wealth unjustly” (QS An-Nisa: 29).

In relation to the verse above with regard to the meaning of al-bathil, Ibn Al-Arabi Al-Maliki, in his book Ahkam Al-Quran, explained that the notion of usury linguistically is added value (ziyadah), however what is revealed in the verse of the Quran is that any additions taken without a substitute transaction justified by Sharia. Substitute transaction meant here is business or commercial transaction that legitimizes the addition in a fair manner such as a purchase-sale transaction, pawn, lease, or profit sharing of a project. Referring to the explanation of the notion of usury and interest above, it can be concluded that interest is the same as usury. 
This is so due to the fact that in the practice of conventional banking, inte rest is payable by the customer to the bank for the loan in the form of an additional charge, because clients do transactions with the bank in the form of loan of cash. In Islam, the concept of loan is known by the term Qard (Qardhul Hasan) which is a goodly loan. Almighty God said: "Who is it that would loan Allah a goodly loan so He may multiply it for him many times over? And it is Allah who withholds and grants abundance, and to Him you will be returned."(QS. Al-Baqarah: 245)

The qard load has no additional charge, so the amount loaned will then be returned in the same amount. However, it is different in the case of a contract or transaction, rent, profit sharing. So, in transactions of business funds, conventionally the lenders take extra interest in the absence of a substitute received by the borrower which is usury that has been forbidden by Allah in the Qur'an and the Hadith as follows: "Allah has permitted trade and has forbidden interest. " (Q. S. Al-Baqarah: 275), and also in the Hadith the Messenger of Allah said, "Jabir said that the Prophet cursed the person who received the usury, the man who paid for it, and one who records it, and two witnesses of this, and then he said, "they are all the same." (Narrated by Muslim, No. 2995 in Al-Musaqqah).

All ulemas (Islamic scholars) agree on the prohibition of usury no matter the amount. A person must not obtain wealth through usury; and the estate should be returned to the owner, if the owner is known, and he is only entitled to the amount he previously owned.

In the context of bank interest, current ulemas in fact have consensus that it is still forbidden. In many occasions of conference, congress, symposium and seminar held by World Islamic economic experts, Umar Chapra foun $\mathrm{d}$ agreement among the scholars concerning the prohibition of bank interest. This means none of the experts said that bank interest is allowed. All of them condemned and prohibited bank interest, both on consumptive or productive, small and large amount, because interest has led to very bad impacts for the world economy and many countries. The world economic crisis which many countries suffered that happened from 1930 until 2009, was the evidence of the most obvious impact of the bank interest system.

The discourse that bank interest is still forbidden for Muslims on the basis of in the development of Sharia banking.

\section{SHARIA BANKING AND ITS FUTURE}

As explained earlier, discourse and discussion about the virtues of Sharia banking in this contemporary era are still driven by the prohibition of usury 
(interest) in conventional banks. Conventional bank interest controversy is still a hot debate in the Indonesian community. This is due to the interest given by conventional banks is considered haraam (forbidden) and the Indonesia Ulema Council (MUI) has issued a fatwa (a ruling given by a recognized authority) regarding the bank interest in 2003. This discourse, however, is still under discussion, since many arguments put forward to justify the interest where some people think that it is not synonymous with usury. Although the Quran and the Hadith have been very clear that it is usury, and the ruling on is clear that it is prohibited.

To address usury appropriately, it requires a deep understanding of the details of the interest as well as of the consequences brought about with the applicable system of interest in the economy and it also requires the interpretation of the signs and direction of the definition of usury in the $\mathrm{Qu}$ ran and the Hadith.

The term 'interest' according to the American Heritage Dictionary of the English Language is «a charge for a financial loan, usually a percentage of the amount loaned ". Interest is an amount of money paid for the use of capital. The amount for example is stated with one level or the percentage of the capital relevant with it which is called the interest of capital (Muhammad Mujahideen, 2010).

The original meaning of "riba" in Arabic is "more" (increased). As for what is mean here by syara, usury is the contract that goes with a particular exchange, the amount is not known or not in accordance the rules of sharia or belatedly accepted (Sulaiman Rasjid, 2002: 290). The term riba was first known based on the revelation handed down at the beginning of the prophetic period in Mecca most likely in the year or the beginning of Hijra. The classical exegetes have argued, that the meaning of riba here is gift. Based on this interpretation, according to Azhari (d. 370 H/980 AD) and Ibn Mandzur ( $\mathrm{d} .711 \mathrm{H} / 1331 \mathrm{AD})$ consists of two forms of usury, one that is forbidden and the other is not. However, in reality the term riba is only used to interpret the value of the debt that added to the loan (Abdullah Saeed, 2003: 27). Meanwhile, al-Jurjani defined usury as an excess payment without any additional/replacement/return, required for one of the two parties that make contract/transaction (Muhammad Mujahidin, 2010).

In this light, generally there is a common definition which asserts that usury is an additional charge, both in buying and selling as well as loan that is wrong or contrary to the principles of muamalat in Islam. Regarding this, Almighty God reminds in His words: «O you who have believed, do not consume one another>s wealth unjustly» (QS An-Nisa: 29). 
In relation to the verse above with regard to the meaning of al-bathil, Ibn Al-Arabi Al-Maliki, in his book Ahkam Al-Quran, explained that the notion of usury linguistically is added value (ziyadah), however what is revealed in the verse of the Quran is that any additions taken without a substitute transaction justified by Sharia. Substitute transaction meant here is business or commercial transaction that legitimizes the addition in a fair manner such as a purchase-sale transaction, pawn, lease, or profit sharing of a project. Referring to the explanation of the notion of usury and interest above, it can be concluded that interest is the same as usury.

This is so due to the fact that in the practice of conventional banking, interest is payable by the customer to the bank for the loan in the form of an additional charge, because clients do transactions with the bank in the form of loan of cash. In Islam, the concept of loan is known by the term Qard (Qardhul Hasan) which is a goodly loan. Almighty God said: "Who is it that would loan Allah a goodly loan so He may multiply it for him many times over? And it is Allah who withholds and grants abundance, and to Him you will be returned."(QS. Al-Baqarah: 245)

The qard load has no additional charge, so the amount loaned will then be returned in the same amount. However, it is different in the case of a contract or transaction, rent, profit sharing. So, in transactions of business funds, convent ionally the lenders take extra interest in the absence of a substitute received by th e borrower which is usury that has been forbidden by Allah in the Qursan and the Hadith as follows: « Allah has permitted trade and has forbidden interest. " (Q. S. Al-Baqarah: 275), and also in the Hadith the Messenger of Allah said, "Jabir said that the Prophet cursed the person who received the usury, the man who paid for it, and one who records it, and two witnesses of this, and then he said, «they are all the same.» (Narrated by Muslim, No. 2995 in AlMusaqqah).

All ulemas (Islamic scholars) agree on the prohibition of usury no matter the amount. A person must not obtain wealth through usury; and the estate should be returned to the owner, if the owner is known, and he is only entitled to the amount he previously owned.

In the context of bankinterest, current ulemas in fact have consensus that it is still forbidden. In many occasions of conference, congress, symposium and seminar held by World Islamic economic experts, Umar Chapra found agreement among the scholars concerning the prohibition of bank interest. This means none of the experts said that bank interest is allowed. All of them condemned and prohibited bank interest, both on consumptive or productive, small and large amount, because interest has led to very bad impacts for the 
world economy and many countries. The world economic crisis which many countries suffered that happened from 1930 until 2009, was the evidence of the most obvious impact of the bank interest system.

Discourse on the prohibition of bank interest has become a basis for Muslims in the development of Sharia banking. In Indonesia itself, the development of Sharia banking has entered a new chapter. The growth of Sharia banking industry has been transformed from merely introducing an alternative to the practice of Sharia banking into how Islamic bank gained its position as a major player in the economic life in the country. Sharia banking has great potential to become the main and first choice for customers in the their transactions. This is indicated with accelerated growth and development of the Sharia bank in Indonesia.

These fundamental differences between the interest-based conventional banks and the system of profit sharing of Islamic banks. See the following table:

\begin{tabular}{|l|l|}
\hline Interest-based & Profit-sharing \\
\hline $\begin{array}{l}\text { The determination of the interest is } \\
\text { made at the beginning of the con- } \\
\text { tract period with projected benefit. }\end{array}$ & $\begin{array}{l}\text { The determination of the ratio for } \\
\text { profit sharing is made at the } \\
\text { time of the contract by analyzing } \\
\text { the possibility of profit and loss. }\end{array}$ \\
\hline $\begin{array}{l}\text { The percentage (\%) of prof- } \\
\text { it is determined unilateral- } \\
\text { ly based on the amount of mon- } \\
\text { ey (capital) loaned multiplied by } \\
\text { the applicable rate of interest. }\end{array}$ & $\begin{array}{l}\text { The ratio for profit sharing is de- } \\
\text { termined based on the amount of } \\
\text { profit obtained in accordance with } \\
\text { the agreement. }\end{array}$ \\
\hline $\begin{array}{l}\text { Interest is paid no matter the busi- } \\
\text { ness run by the customer results } \\
\text { in profit or loss. }\end{array}$ & $\begin{array}{l}\text { Profit-sharing is done based on the } \\
\text { profit from the business run. How- } \\
\text { ever, when loss occurs, it will be } \\
\text { borne jointly by both parties. }\end{array}$ \\
\hline $\begin{array}{l}\text { Interest given to the custom- } \\
\text { er is fixed } \\
\text { though bank profitability has in- } \\
\text { creased. } \\
\begin{array}{l}\text { Interest (usury) is contrary to } \\
\text { the principles of Sharia. }\end{array}\end{array}$ & $\begin{array}{l}\text { Profit-sharing with } \\
\text { customers increases, as the bank } \\
\text { gains more profit. } \\
\text { Profit-sharing is in accordance } \\
\text { with the principles of Sharia. }\end{array}$ \\
\hline
\end{tabular}

Sharia banking industry until now, according to Yuli Trisnawati is enjoying growth better than it did in 2009. This refers to the results of an analysis of the fundamental condition of the macro-economic in the world's economy that is likely to recover, as well as the internal dynamics of the Sharia bank- 
ing industry (Yuli Trisnawati, 2011).

The factors supporting Sharia banking industry are, among others, the non-organic growth due to the increase of new players in the industry, including public banks, Sharia Business Units (UUS) and the BPRS (Sharia banks specializing in loans). In 2009, the number of Sharia banks increased with the conversion of 3public banks i.e. Bank Jasa Artha, Bank Persyarikatan and Bank Hasfa each of which was acquired by Bank BRI, Bukopin and Bank Panin to become Sharia public banks The growth in such non-organic was also supported with organic growth through the increased volume of business supported by an increasing number of Sharia bank offices network. As of early November 2009, the public could to enjoy banking services through the 1,101 Sharia banks operated by 6 public Banks, and 25 UUS Sharia Business Units) and 138 BPR (People's Credit Banks). This year, opportunities for increased business volume of Sharia banking were open. The reason is that the rate of Indonesia's economic growth next year is still relatively high, along with credit rating that is also enjoying an increase. The educational programs and dissemination of Sharia banking by Bank Indonesia, have caused Sharia banking and other associated parties increasingly to create conducive situation to the capital market industry (Yuli Trisnawati, 2011).

Research conducted by an Islamic Bank on approximately 3,200 customers throughout Indonesia revealed that over $70 \%$ of the customers chose the Sharia bank for their banking transactions because of religious beliefs. This indicated that there are still many people who do the financial transactions that do not conflict with religious beliefs. $38 \%$ of the respondents cited quick and satisfactory service as the reason to choose Sharia banks and 30\% due to the strategic location of the bank's office, in addition to other rational reasons.

With regard to the discussion above, the actual Sharia economic prospects, particularly Sharia banking is promising in the future. This is due to the existence of consciousness in part of the community, especially the highly educated to run economic social life without leaving the values of Islam. This trend should be anticipated with readiness and infrastructure to support the development of the economy of optimally in future. The facilities and infrastructure meant here are not only in the physical form, but also non-physical such as the education systems that accommodate those needs, so that the human resources will have the capability to build and develop the Sharia economy in the future

Specifically, the performance of Sharia banking on national funding (thirdparty funds) showed encouraging growth. Sharia banking industry is still able to maintain high growth of the DPK, where year-over-year growth 
rates until October 2011 was 43\%. It was expected in 2011 that the DPK of Sharia banks would still grow rapidly given the Sharia banking network was also significantly increasing as a result of the emergence of new Islamic banks in the previous year. In the meantime, Sharia financing was also expected to enjoy increased growth rate. Until October 2010, the year-over-year growth in Sharia banks financing reached 39\%, far above the conventional bank credit growth. This figure is certainly more or less presented the contributions of Sharia banking against the corporate world nationwide, especially the world of micro enterprises (Yuli Trisnawati, 2011).

Though Sharia banking enjoyed high growth, however, the industry still had to overcome some of the challenges, in order to maintain a sustainable growth. There are at least 5 major challenges to the Sharia bank. First, the human resources. With the ever increasing number of Sharia banks and Sharia Business Units in the future, the demand for sufficient numbers of qualified human resources is also increasing. Third, the regulation aspect. The development of Sharia banking is inseparable from the regulatory aspect. If the legal condition is not conducive, it certainly will hinder the growth of Sharia banking, therefore the support of the legal aspects is urgently required. Therefore, Sharia economic community and Islamic economic organizations in Indonesia as well as the MUI (Indonesian Ulema Council) should urge the Government to immediately issue laws related to Islamic banking. Fourth, the optimization of the network service. The opening office channeling in Shariah banks which began in March 2006 and through 2007 increased quite significantly. The policy of office channeling basically focused on addressing the problem of limited banking service coverage. However, it was not balanced with the educational and socialization programs. Fifth, product innovation. The success of the Sharia banking system in the future will depend on the ability of Sharia banks to come with attractive and competitive products that meet the needs of the community, but in accordance with the principles of the Sharia, and that's why Sharia banks should be more creative and innovative in the design of its products.

According to the identification of Bank Indonesia, presented at a seminar in late 2005, the constraints of the development of Sharia banking in addition to macro-economic condition, were also affected by the following: first, the limited office network. Second, the limited professional and competent human resources. Third, the lack of enthusiasm among members of the community despite their knowledge of Islamic banks. Fourth, the lack of policy synchronization with other government institutions related to financial transactions, such as tax policy and legal aspects. Fifth, the high interest 
rate regime in 2005 (Yuli Trisnawati, 2011).

Bank Indonesia and other related stakeholders should be convinced that the development of Sharia banks has a high prospect if the network barriers can be overcome. The prospects are as follows: first, the enthusiastic response from people in doing economic activities by using the principles of Shariah. Second, the development of Islamic financial instruments is expected to be increasingly attractive to investors/business entry and will improve national Sharia banking industry. Third, the investment potential from the Middle Eastern countries in the Sharia banking industry nationwide.

The challenges clearly visible regarding the future of the national Sharia banking is how to keep the growth rate of this financial institution with a good performance. In addition, another challenge that also needs to be aware of is that Sharia banking is concentrating too much on the low risk contracts especially the economic sectors which are limited in variety and still dominant in the trade and service sectors.

Apart from this visible physical development, it is expected in the coming years that the development of the national Sharia banking industry will also increasingly show its advantage in the form of benefit for the community members, particularly the disadvantaged people. Therefore, the developmental variables or the degree of benefit should probably be introduced so as to serve as a parameter of the National Sharia banking for the community members that have not been reached by the conventional banking industry.

\section{CONCLUSION}

In the perspective of contemporary fiqh (Islamic jurisprudence), the conventional bank interest controversy which is still debatable in society, has somehow been responsible for Sharia banking growth in Indonesia. In this context, all Islamic scholars agree that usury is forbidden, no matter the amount. A person must not control wealth through usury; and the capital should be returned to the owner, if the owner is known, then he is only entitled to the amount he loans only. In the context of bank interest, current scholars have a consensus that bank interest is forbidden.

Therefore, looking at the trend of the rapid growth and development of Sharia banking, there is hope for all of us (Muslims) that Sharia banking is expected to be able to generate national economic growth and development. Thus, the future of Sharia banking is measured from how far it is able to maintain the pace of growth with an excellent performance. Other challenges that should 
also be noted in this regard is that Sharia banking is still concentrating on the low-risk contracts that include only products in the service and trade sector.

Despite visible physical development, it is expected in the coming years that the development of the national Sharia banking industry will also give benefit to the disadvantaged community members. Therefore, the developmental variables or the degree of benefit should probably be introduced so that Sharia banking will be able to serve as a parameter for those that have so far not been reached by the established banking industry. To sum up, the future of Sharia banking is strongly associated with the commitment from Islamic banking management and support from many parties, particularly the Muslims themselves (who historically practiced Islamic banking), so that not only will it exist but the national Sharia banking will also be able to play a significant role in the national development, and more broadly in the support of national economy. ${ }^{* *}$

\section{REFERENCES}

Abdullah Saeed, 2003. Bank Islam Dan Bunga, Yogyakarta: Pustaka Pelajar. Adiwarman A. Karim, 2004. Bank Islam: Analisis Fiqih dan Keuangan. Jakarta: Rajawali Press.

Departemen Agama, 1995. Al-Quran dan Terjemahannya. Yogyakarta: Dana Bhakti Waqaf.

Karnaen A. Perwaatmadja dan M. Syafi'I Antonio, 1997. Apa dan Bagaimana Bank Islam. Yogyakarta: Dana Bhakta Wakaf.

Muhammad Mujahidin, 2010. “Analisis Fiqh Kontemporer Terhadap Keter-

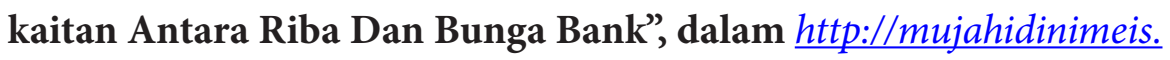
wordpress.com/2010/05/02/analisis-fiqh-kontemporer-terhadap-keterkaitan-antara-riba-dan-bunga-bank/ (akses internet tanggal 27 September 2014)

Sulaiman Rasjid, 2002. Fiqh Islam, Sinar Baru Algesindo, Bandung.

Umer Chapra, 1999. Islam dan Tantangan Ekonomi Kontemporer. Yogyakarta: Risalah Gusti.

Yuli Trisnawati, 2011. "Prospek Pertumbuhan Bank Syariah", dalam http:// yullitrisnawati.blogspot.com/2011/04/prospek-pertumbuhan-bank-syariah-dan.html. (akses internet tanggal 27 September 2014).

Undang-Undang Republik Indonesia Nomor 21 Tahun 2008 Tentang Perbankan Syariah

Yusuf Wibisono, 2009. Politik Ekonomi UU Perbankan Syariah Peluang dan Tantangan 